\title{
НАУКОВІ ФОРУМИ ТА НОВІТНІ ТЕХНОЛОГІЇ НА СЛУЖБІ ОСВІТИ НА НОВОМУ ЕТАПІ ВПРОВАДЖЕННЯ КМСОНП
}

\author{
В. М. Запорожан, В. Й. Кресюн, О. В. Чернецька, Л. С. Годлевський
}

Одеський начіональний медичний університет

\section{THE SCIENTIFIC FORUMS AND NEWEST TECHNOLOGIES TO HELP EDUCATION AT THE NEW STAGE OF INTRODUCING THE CREDIT- TRANSFER SYSTEM}

\author{
V. M. Zaporozhan, V. Y. Kresyun, O. V. Chernetska, L. S. Hodlevskyi \\ Odesa National Medical University
}

\begin{abstract}
У роботі зроблено акцент на важливості проведення значної низки форумів різного рівня для спілкування та обміну досвідом науковців на новому етапі впровадження кредитно-модульної технології.

The work emphasizes the importance of holding a number of forums of different levels for discussion and experience exchange by scientists at the new stage of introducing the credit-transfer technologies.
\end{abstract}

Вступ. Успішне вирішення стратегічних завдань у контексті реформування галузі охорони здоров'я можливе завдяки поліпшенню якості підготовки медичних спеціалістів, оптимальній організаціїпіслядипломної освіти фахівців у ВМНЗ МОЗ України з урахуванням потреб регіонів у кадровому забезпеченні.

Функціонування інноваційного суспільства здійснюється за рахунок інтенсивного та масштабного передавання нових знань, що генеруються в університетах, включаючи технології в різних (природничо-наукових, соціально-гуманітарних, професійно орієнтованих) галузях діяльності. Останнім часом для відображення подібних функцій використовується новий термін - “інноваційний університет”. Сучасний трансфер знань відображає систему організації багатоканального та багаторівневого інтерфейсу між університетом і його зовнішнім оточенням, передусім суб' єктами навчання та лікувальними базами з високими технологіями. Сервер дистанційного навчання наповнено електронними навчально-методичними матеріалами. Потужний арсенал навчально-методичних ресурсів, інтерактивні елементи, гнучка та цікава система зворотного зв'язку перетворює сервер з навчальної веб-платформи на своєрідну соціальну мережу університетської спільноти. Статистика відвідування сервера сприяє позиціям університету у рейтингу, таким чином зросте його популярність, що надає можливість визначити його місце серед університетів світу за показником їх на- явності в мережі Інтернет "Web metrics Ranking of Worlds Universities".

Основна частина. За останній час науково-педагогічним складом університету проведено з'їди та низку міжнародних, республіканських конференцій, наукових форумів.

В рамках Міжнародного російсько-українського науково-дослідного проекту РГНФ-НАНУ“"Постнеклассические практики в изменяющемся мире" (проект № 008-03-91309aU; постанова Президії НАН України № 125 від 23.04.2008 р.; постанова Президії НАН України № 96 від 08.04.09, проект № 18) організовано та проведено (12 вересня 2011 року) науковопрактичну конференцію IX Пригожинські читання “Философия и наука на постнеклассическом этапе: исследования человекомерности, диссипативности, сложности". В роботі конференції взяли участь провідні фахівці з Росії та України, академіки Російської академії наук, професори російської Академії державної служби при Президенті РФ, члени Української синергетичної спілки, науково-педагогічний склад ОНМедУ та інших ВНЗ міста Одеси. На пленарних та секційних засіданнях зроблено понад 40 доповідей з актуальних питань філософії.

На високому рівні проведено VIII з'їзд акушерівгінекологів України (21-23 вересня 2011 р., Одеса). В дні роботи з'їзду на 25 симпозіумах зроблено понад 260 доповідей, в тому числі 35 стендових, а також проведено 2 майстер-класи. В роботі з'їзду взя-

() В. М. Запорожан, В. Й. Кресюн, О. В. Чернецька, Л. С. Годлевський 
ли участь провідні спеціалісти з України, Німеччини, Польщі, Росії, Естонії, Мальти, Азербайджану та ін.

На базі університету 29 вересня - 01 жовтня 2011 р. проведено Міжнародну науково-практичну конференцію, присвячену 10-річчю ДУ “Інститут нефрології НАМН України” - “Достижения в нефрологии, диализе и трансплантации почки”. Під час роботи конференції зроблено понад 150 доповідей відомих фахівців України, Росії, США, Німеччини, Швеції тощо.

6-7 жовтня 2011 р. відбулася науково-практична конференція, присвячена 100-річчю $з$ дня народження професора I. В. Савицького "Коферменти в медичній практиці”. Зроблено понад 50 доповідей, вручено сертифікати учасникам конференції, прийнято резолюцію.

У грудні 2011 р. традиційно відбулася чергова Міжнародна дистанційна конференція "Біофізичні стандарти та інформаційні технології в медицині”, в якій взяли участь фахівці з України, Росії, Казахстану, Туреччини, Польщі. Видано матеріали конференції. Надруковано 103 роботи 192 авторів, 13 статей 38 авторів.

Відбулися й інші конференціі:

- науково-практична конференція “Сучасні підходи до гормонотерапії при невиношуванні вагітності” (січень, 2012 р.);

- науково-практична конференція “Актуальні питання лікування кислотозалежних захворювань і ШКТ в практиці лікаря" (17.02.2012 p.);

- науково-практична конференція з міжнародною участю “Діагностика, профілактика та комплексна корекція порушень гемостазу в кардіології, електрофізіологї та кардіохірургї” (15.03.2012 р.).

5-6 квітня 2012 р. відбулася науково-практична конференція з міжнародною участю “Новітні технології в педіатричній науці, практиці та освіті”, присвячена пам'яті академіка НАМН України Б. Я. Резника. На засіданнях конференції були представлені понад 100 доповідей із найбільш важливих питань сучасної педіатрії. В дні роботи конференції проведено робочу нараду опорної кафедри щодо викладання педіатрії англійською мовою та робочу нараду опорної кафедри щодо викладання біоетики та біобезпеки.

Організована VII Південноукраїнська науково-практична конференція “Сучасні проблеми атеросклерозу - від гіпотез до фактів” (Одеса, 11 квітня 2011 р.). Заслухано 30 доповідей відомих фахівців України 3 проблем атеросклерозу, артеріальної гіпертензії, раціональної терапії IXC, ХCH, ОКС тощо. Надруковано в матеріалах конференції 153 роботи, учасники отримали сертифікати.
У квітні 2012 року в ОНМедУ пройшла щорічна виставка “Ліки. Медицина. Стоматологія", відвідувачі якої могли ознайомитися з новітніми стоматологічними технологіями та придбати сучасні стоматологічні матеріали, інструментарій та інше. В рамках проведення виставки відбулися майстер-класи зі стоматології.

За традицією університету відбулася Міжнародна конференція студентів та молодих вчених “Молодь - медицині майбутнього”, яка в цьому році була присвячена 155-річчю $з$ дня народження видатного вченого В. В. Підвисоцького (19, 20 квітня 2012 р.). В рамках конференції пройшли секційні засідання, “круглий стіл” та пленарне засідання. Всього на конференції було подано 559 робіт, 3 них 203 - студентами та молодими вченими ОНМедУ і 356 - учасниками з інших навчальних закладів Києва, Харкова, Москви, С.-Петербурга, Казані, Саратова, Мінська та інших. Надруковано збірник тез наукових доповідей.

Як і завжди, науково-педагогічний склад ОНМедУ 26-27 квітня 2012 р. взяв участь у роботі Всеукраїнської наукової навчально-методичної конференції “Впровадження нових технологій за кредитно-модульної системи організації навчального процесу у ВМ(Ф)НЗ III-IV рівнів акредитації, що відбулась у м. Тернополі. У матеріалах конференції надруковано 48 робіт 156 авторів університету, зроблено 19 доповідей з проблем ефективного впровадження КМСОНП у медичних ВНЗ тощо.

11-12 травня 2012 р. проведено науково-практичну конференцію $з$ міжнародною участю “Сучасна реконструктивна стоматологія. Міждисциплінарний підхід”. В роботі конференції взяли участь представники наукової еліти з Донецька, Львова, Івано-Франківська, Києва, Вінниці, Запоріжжя, Полтави, Харкова, Чернівців тощо. Надруковано 64 роботи 123 авторів.

17-19 травня 2012 р. на базі кафедри фізичної реабілітації, спортивної медицини, фізичного виховання і валеології ОНМедУ відбулася науково-практична конференція з міжнародною участю “Спортивна медицина, лікувальна фізична культура та валеологія 2012”. У роботі конференції взяли участь понад 100 фахівців з 23 міст України. В рамках конференції відбулися засідання координаційної ради МО3 України 3 питань фізичної реабілітації та спортивної медицини та сумісна семінар-нарада завідувачів кафедр фізичної реабілітації, спортивної медицини, фізичного виховання і валеології ВМНЗ MO3 України III-IV рівнів акредитації. Надруковані матеріали конференції-142 роботи 319 авторів. 
24-25 травня 2012 р. проведена науково-практична конференція з участю міжнародних фахівців “Актуальні питання діагностики і лікування захворювань внутрішніх органів" та I Міжнародна чорноморська науково-практична конференція "Сучасні аспекти кардіології”. Зроблено 24 доповіді, проведено майстер-клас з рентгенендоваскулярної хірургії, здійснено пряму трансляцію з рентгенопераційної кардіологічної лікарні Святої Катерини.

24-26 травня відбувся II Українсько-російський конгрес анестезіологів. Зроблено понад 30 доповідей провідних фахівців України (Київ, Львів, Дніпропетровськ, Донецьк, Харків, Луганськ тощо), Росії (Санкт-Петербург, Тольятті, Москва, Красноярськ, Іжевськ, Архангельськ, Кемерово, Ярославль тощо), Білорусі(Мінськ).

Щорічно науково-педагогічний склад ОНМедУ бере участь у роботі Всеукраїнської науково-методичної конференції “Сучасні технології вищої освіти”, яка проводиться на базі Одеської національної академії харчових технологій (м. Одеса, 3-5 жовтня 2012 р.). У матеріалах конференції надруковано 50 робіт 124 авторів університету, зроблено 7 доповідей з проблем використання сучасних технологій навчання.

Співробітники ОНМедУ взяли активну участь у роботі IV Всесвітнього саміту лікарів-ендоскопістів (2-5 жовтня 2012 р., м. Київ).

Також при активній участі науковців університету проведена Всеукраїнська науково-практична конференція $з$ міжнародною участю до 215 річниці Військово-медичного клінічного центру Південного регіону (411 Окружного військового ордена Червоної Зірки госпіталю) "Військова хірургія - сучасна концепція надання екстреної та високоспеціалізованої медичної допомоги" (10-12 жовтня 2012 р., м. Одеса). Зроблено 32 доповіді.

На базі університету проведена науково-практична конференція з міжнародною участю “Сучасна дентальна імплантація” (8-9 листопада 2012 р.).

Взяли участь науковці з Молдови, Литви, Чехії, Росії, Німеччини, Ізраїлю, Вірменії, Азербайджану.

Крім цього, на базі університету співробітниками ОНМедУ 22-23 листопада 2012 р. проведена науково-практична конференція 3 міжнародною участю "Актуальні питання діагностики і лікування рухових порушень (захворювання нервової системи 3 порушенням рухів)". Взяли участь лікарі з Бельгії, Данії, Італії, Франції, Великобританії, Німеччини, Хорватії.

Відбувся 13 березня 2013 р. у м. Одесі під егідою Національної асамблеї інвалідів України спільно 3 ОНМедУ та Міжнародною мережею надавачів по- слуг для дітей/дорослих з інвалідністю SOFT Tulip (Нідерланди), Socires (Нідерланди) “круглий стіл”: "Ранній розвиток дитини з особливими потребами: важливість міждисциплінарного та міжвідомчого підходу", діалог на якому буде сприяти налагодженню співпраці між державними та громадськими інституціями в Одеському регіоні у наданні послуг сім'ям, а також створенню простору для впровадження нових доказових підходів та методів.

Проведена (для молодих вчених та студентів) науково-практична конференція з міжнародною участю "Сучасні теоретичні та практичні аспекти клінічної медицини” (14-15 березня 2013 р., м. Одеса). В дні роботи конференції здійснились 17 секційних засідань та “круглий стіл”, присвячений 100-річчю 3 дня народження проф. К. Д. Двужильної. Зроблено 235 доповідей, надруковано понад 400 наукових праць.

Всі сучасні форуми проводяться з використанням найновітніших технічних засобів. Унікальним технічним рішенням, що значно розширює можливості аудиторного мультимедійного комплексу, є застосування в аудиторіях веб-камер. Останні дозволяють проводити інтерактивні відеоконференції та веб-семінари, а також відеозапис лекцій. Інтерактивна відеоконференція сьогодні $є$ одним з ефективних засобів дистанційного навчання, спілкування, максимально наближеного за своїми параметрами до реального, яке використовують у найрізноманітніших сферах навчально-виховної та наукової діяльності. Зараз є можливість здійснювати лекції і режимі online для багатьох категорій слухачів у різних регіонах світу.

Медична практика постійно вимагає від лікарів прийняття клінічних рішень у складних та непередбачуваних обставинах, що обумовлює потреби як у формалізованому навчанні, так і в аналізі власної лікарської діяльності та в обміні досвідом і діалозі 3 колегами. Проте у лікаря має бути не лише мотивація до постійного підвищення свого професійного рівня, але й можливість ії реалізації в конкретних програмах і заходах. Одним з вагомих заходів $\epsilon$ проведення форумів. У проведенні та роботі форумів беруть активну участь студенти, інтерни, магістри та клінординатори університету. Значно підвищує рівень професіоналізму слухачів можливість заслуховувати наукові доповіді провідних фахівців у різних галузях медицини та змога обміну досвідом під час роботи з'їздів, конференцій, симпозіумів тощо. Все це сприяє здійсненню безперервної освіти на якісно високому рівні. Крім того, сьогодні в процесі реалізації безперервного професійного розвитку зростає роль періо- 
дичних видань та Інтернет-ресурсів професійних лікарських асоціацій, а також науково-практичних конференцій за певними спеціальностями та/або присвячених певним проблемам клінічної практики, що надають лікарям можливості як для ознайомлення 3 новими даними доказової медицини, так і для спілкування 3 колегами.

Втім, сучасні проблеми глобалізації та побудови суспільства, орієнтованого на знання, породжують $і$ нові вимоги як для лікарської спільності, так і для окремих лікарів. Зворотним боком колосального інформаційного потоку виявляється те, що нині актуальною проблемою $є$ не стільки отримання наукової

\section{Література}

1. Управление качеством подготовки специалистов: программно-целевой подход (на примере высшего и послевузовского медицинского образования) : монография / [В. Н. Казаков, Н. А. Селезнева, А. Н. Талалаенко и др.].Москва-Донецк : Исследовательский центр проблем ка- інформації, скільки іiї систематизація та аналіз у межах конкретної лікарської спеціальності або певної клінічної та освітньої проблеми.

Висновок. Таким чином, умовою здійснення безперервного професійного розвитку є обов'язкова участь у роботі з'їздів, конференцій, симпозіумів тощо. А оскільки Україна чітко визначила орієнтир на входження в освітній і науковий простір Європи, здійснюючи модернізацію освітньої діяльності в контексті європейських вимог, найважливішою педагогічною основою вузівської освіти є конкурентоспроможність на основі стандартів якості, що забезпечує на новому етапі використання КМСОНП.

чества подготовки специалистов, Донецкий государственный медицинский университет, 2003.-215 c.

2. Медична освіта в Україні / [І. С. Булах, О. П. Волосовець, В. С. Москаленко та ін.]. - К. : Книга плюс, 2005. $384 \mathrm{c}$. 